\title{
The relationship of burnout with workaholism mediated by work-family life conflict: A study on female academicians
}

\author{
Eda Ercan Demirel ${ }^{\text {* }}$ (D), Meral Erdirençelebi ${ }^{\text {b }}$ (io) \\ ${ }^{a}$ Necmettin Erbakan University, Konya, Turkey \\ ${ }^{b}$ Necmettin Erbakan University, Konya, Turkey
}

\section{APA Citation:}

Ercan Demirel, E., \& Erdirençelebi, M. (2019). The relationship of burnout with workaholism mediated by work-family life conflict: a study on female academicians: Journal of Language and Linguistic Studies, 15(4), 1300-1316.

Submission Date:07/09/2019

Acceptance Date:30/10/2019

\begin{abstract}
Along with the teaching, institutional, and administrative responsibilities, female academicians carry out some other roles such as motherhood, being a wife, having responsibilities related to household issues, as well. Researchers of the study- from the very inside of the academy as females with many different roles- had the urge to examine the case of female academicians. The study investigated the case of female academicians -the relationship of burnout with workaholism mediated by work-family life conflict. On quantitative research design, a questionnaire was conducted on 207 female academicians of a state university. Frequency distribution, explanatory factor analysis, confirmatory factor analysis, correlation analysis, and SEM were carried out. It was found out that $23 \%$ of work-family life conflict was related to workaholism; $32 \%$ of burnout was related to workaholism; $19 \%$ of burnout was related to work-family life conflict. Along with the purpose of the study, $11 \%$ of the female academicians' burnout was found to be resulting from the effect of workaholism mediated by workfamily life conflict. As female academicians were found to be victims of burnout resulting from workaholism mediated by work-family life conflict; female academicians should be supported by seminars, trainings, and guidance on self-confidence, time and stress management, raising awareness towards workaholism, strategies to cope with burnout. Further studies should be on the underlying reasons of the issue.
\end{abstract}

(C) 2019 JLLS and the Authors - Published by JLLS.

Keywords: Female academicians; Burnout; Workaholism; Work-family life conflict; Structural Equation Model (SEM).

\section{Introduction}

\subsection{Theoretical Background}

\subsubsection{Burnout Phenomenon}

The term "burnout" might be regarded as dating even far back to the history of humankind. However, it was first defined in 1970s (Budak \& Sürgevil, 2005, p.95). Coined by Herbert Freudenberger (Ercan Demirel, 2014, p.23), the term was only introduced to the world of social sciences in 1974. As a term, "Burnout" (Freudenberger, 1974) phenomenon covers both physical and emotional exhaustion and also

${ }^{*}$ Corresponding author. Tel.: +0-536-324-0248 
negative attitudes stemming from intensive work-life (Chan, 2007, p.34). Simply, burnout might be defined as "feeling exhausted, out of energy, unable to make it to the end." It can be referred to as continuous and acute feeling of tiredness and unwillingness, as well.

Stress has always been a part of our lives. Upon the globalised world, having illnesses caused by stress more commonly, it has become an urge to cope with the daily stress and its final consequentburnout. Therefore, recently many research studies have focused on the case of burnout, factors that cause burnout, and how to cure.

The term is not only restricted to the field of human-work. The concept of burnout has been generalised to a wider understanding related to the people who do not do human work as well (Schaufeli, Taris \& Bakker, 2002); however, the origins of the phenomenon dwell on human work basically (Maslach, Schaufelli \& Leiter, 2001). The fact that especially human services being under threat makes teaching professionals some kind of "endangered species". Teaching profession is one which requires much effort to fully devote oneself, and already demanding by itself, burnout makes it unbearable at all. Academicians in a way represent the pillars of the education sector (Rampal \& Shahar, 2014, p.51) as they finalise the training of the students and prepare them for their future careers. Putting the burden of other academic and administrative responsibilities on the shoulders of the academic staff, academicians might be accepted as other victims of burnout phenomenon.

Burnout is credited to have three basic dimensions as emotional exhaustion, depersonalisation, and reduced personal accomplishment. Dimensions of burnout might also be explained within phases, as well; completing one after the other, finally burnout is complete. Emotional exhaustion might be regarded as experiencing the collapse of feelings. It is simply the depletion of emotional reserves (Watts \& Robertson, 2011, p.34) and characterised by wearing out, loss of energy, depletion, debilitation, and fatigue (Maslach, 1999, p. 215). Emotional exhaustion might be associated with an individual whose battery is about to die emotionally.

Starting with the first stage-emotional exhaustion- comes the second stage as expecting the unexpected. Once emotional exhaustion sets in, people feel they are no longer able to give of themselves to others (Maslach, 2003, p.3), which leads to depersonalisation. Depersonalisation refers to a callous reaction (Greenglass, Burke \& Konarski, 1998, p.1088) and an increasingly cynical and negative approach towards others (Watts \& Robertson, 2011, p.34). Literally, when the final stage of the phenomenon sets in, the person directly goes through a growing feeling of work-related dissatisfaction (Watts \& Robertson, 2011, p.34) - the diminished personal accomplishment stage and experiences 'the tendency to evaluate oneself negatively, particularly with regard to one's work with clients' (Maslach \& Jackson, 1981, p.99). Completing the three stages of burnout, unfortunately an ongoing process begins towards the end, unless some precautions are taken against.

Being one of today's challenges of every day, stress is everywhere causing many problems. Stress and stressful working environment (Toker, 2011, p.114) are accepted as basis for burnout and even "occupational stress" is interchangeably and synonymously used as "burnout" (Schaufeli \& Enzman, 1998, p.8). Lack of resources, neglected recognition of efforts, responsibility for academic success and student achievement (Chan, 2007, p.35), high job demands, workload, lack of motivation (Schaufeli \& Enzman,1998, p.8) are directly seen to be associated with the burnout issue. Considering the aforementioned threats, academicians are left in the face of a burnout danger.

Tension, anxiety, stress, all coming together with other factors are becoming bricks and mortar and building the 'wall of burnout'. Taking the burnout case into educational context, it might be accepted to be leading to risks both within the careers of the teachers, and the learning outcomes of students (Chan, 2007, p.35) as well. Academia is not seen as a low-stress working place any more (Watts \& Robertson, 
2011, p.34). The danger is sneaking up to nearly all academicians and pushing them into stress, burnout, and finally quitting job and resign.

While experiencing all three dimensions and stages of burnout, the victims might be facing some symptoms. These symptoms might be as such: lack of enthusiasm for work, helplessness, frustration (Melendez \& Guzman, 1983 p. 11), absenteeism, intention to leave the job, lower productivity and effectiveness, decreased job satisfaction, problems of physiological and mental health (Maslach et al, 2001, p.406), depression, feeling of inadequacy and lack of self-esteem. Regarding the symptoms, it is obvious that victims experience and suffer from symptoms of all sources-emotional, psychological, physiological, social and sometimes economical.

Another indicator of the phenomenon could be on social life. There is also some evidence on the negative effects of burnout on individual's private life-related variables (Burke \& Greenglass, 2001). Considering contagious effects on the job (Maslach, et al., 2001, p.405), burnout should not be seen as something only individuals are facing, rather a threat against all members of academia, which must be fought against. Followed by the dimensions and the three stages of burnout, the victim is dangerously, gradually, and eventually facing the truth and is finally forced to choose a path- either fight or flight!

\subsubsection{Workaholism}

Workaholism might be simply defined as being addicted to working. Coined as a term by Oates in the late 1960s, workaholism phenomenon was described as "uncontrollable need to work incessantly" (Oates, 1971, p.11). This 'need to work' is completely intrinsic than extrinsic (Shimazu \& Schaufeli, 2009). Not even motivated by outside factors, workaholics feel an urge or impulse to work, instead. Workaholism should not be handled as a concept only confined to over-time spent at work, rather the 'addictive nature' of itself should be considered (Shimazu \& Schaufeli, 2009, p. 495-496). This nature might be explained through intrinsic motivation, and uncontrollable characteristic.

Workaholics experience a kind of uneasiness when they are not on 'work', so they keep working. As the name suggests, the term is associated to a kind of "addiction", and with its symptoms, workaholism is put into a similar category as alcoholism, drug addiction, and gambling addiction (Doğan \& Tel, 2011). Porter (1996) correlated workaholic behaviour with the low self-esteem or un/der developed selfconcept and workaholism might be explained by compensation of these concepts with excessive work. The case might be explained simply within a few words: the lower self-esteem is, the more workaholism to be faced.

Being a factor directly related to self-esteem, workaholism might be considered as risky in terms of burnout, as well. Having two factors interrelated, individuals facing and suffering from these problemsburnout and/or workaholism- have difficulty in adapting work-life, family- life, and social life to a large extent. In total, it makes work-family life balance very difficult to handle, even harder for the femalesalong with the other roles to pursue.

\subsubsection{Work-Family Life Conflict}

Two basic concepts have dominance over the lives of adults: work-life and family life. Each concept has individual responsibilities to take care of and spare time to fulfil the tasks related. A perfect balance between these two has great impact on individual's life in terms of mental health, physical health, lifesatisfaction and self-confidence.

To meet the needs of both sides, the individual sometimes has conflicts on which role to give priority first, what requirements to fulfill, and gives dominance over the other, and finally neglects one. These conflicts might be categorised under three groups as time-based conflict, strain-based conflict, and behaviour-based conflict (Netemeyer, Boles \& McMurrian, 1996; Greenhaus \& Beutell, 1985). The more conflict individuals have related to the roles, the lower their life satisfaction levels are (Kossek \& 
Ozeki, 1998). This might also lead to dissatisfaction with the work, as well, which also may bring the case to be explored as an element within the 'burnout \& work-family life balance' context. All in all, work-family life balance is a challenge which is very demanding to keep- even harder for females with very many different roles to consider. Thus, work-family life balance should be regarded as a fragile case to be handled with care especially within the context of females.

\subsubsection{Previous Studies}

Up till now, there have been many studies focusing on the burnout phenomenon. The case has been subject for research since 1970s (Freudenberger,1974; Maslach, 1976). Many different studies were conducted in the fields of education, medicine, business, engineering, sports (Maslach \& Jackson, 1981; Çapri, 2006; Schaufeli et.al., 2002). As regards the focus of the study- educational field- teachers, administrators, academicians, supervisors were in question. Teachers were the subjects of some studies (Greenglass et. al. 1998; Skaalvik \& Skaalvik, 2010; Chan, 2007). Narrowing the focus down, there have been studies on the burnout of the academicians (Ercan Demirel \& Cephe, 2015; Watts \& Robertson, 2011; Doyle \& Hind, 1998; Budak \& Sürgevil, 2005; Toker, 2011; Khan, Khan \& Naz, 2016; Rampal \& Shahar, 2014).

Further research studied the relationship between job satisfaction and burnout (Hooigard, Giske, \& Sundsli, 2011; Arslan \& Acar,2013); work engagement, workaholism and burnout (Stoeber \& Damian, 2016; Schaufeli, Taris \& Rhenen, 2008); workaholism, work engagement, and well-being (Shimazu \& Schaufeli, 2009); workaholism, work-life conflict, and life satisfaction (Bonebright, Clay \& Ankenmann, 2000); work-family life relations and burnout (Tuğsal \& Ülgen, 2017; Troppmann \& Troppmann, 2012; Özkin, 2015); however, only a thesis study conducted on workaholism, work-family conflict, burnout (Macit, 2015) has been found.

Having three elements, with the predictors, antecedents, symptoms so inter-related, and having so much research on the relations between the elements, a need arises to examine the relationship among all concepts- burnout, work-family life balance, and workaholism. Having a lack of research on the relationship among all, the present study was conducted.

\section{Method}

With the increasing demands of the modern age; workaholism, burnout, and work-family life conflict have become common issues of daily life, and almost no one left unaffected by one. Melendez and Guzman (1983) assert living in a highly competitive world of academia, faculty members suffer from increasing pressures to teach, to produce research, handling dissatisfactions, and thus become possible candidates for facing stress and burnout consequently. Not a safe place as it seems, academy is taken as a place to experience and study them all.

Along with the teaching, institutional, and administrative responsibilities, engagements, and obligations, female academicians carry out some other roles such as motherhood, being a wife, having responsibilities related to household issues, as well. Researchers of the study- from the very inside of the academy as females with many different roles had the urge to examine the case of the female academicians. The study was also significant to be conducted by researchers who were also likely to experience the concepts under study.

The study tries to shed light on the case of female academicians in terms of burnout, workaholism and work-family life conflict. The relationship of burnout with workaholism mediated by work-family life conflict were examined within the study. With this aim in mind, the following hypotheses have been formulated. 
$\mathrm{H}_{1}$ : Workaholism levels of the female academicians positively affect work-family life conflict.

$\mathrm{H}_{2}$ : Workaholism levels of the female academicians positively affect burnout levels.

$\mathrm{H}_{3}$ : Work-family life conflict levels of the female academicians positively affect burnout levels.

$\mathrm{H}_{4}$ : Workaholism levels of the female academicians positively affect burnout levels mediated by work-family life conflict.

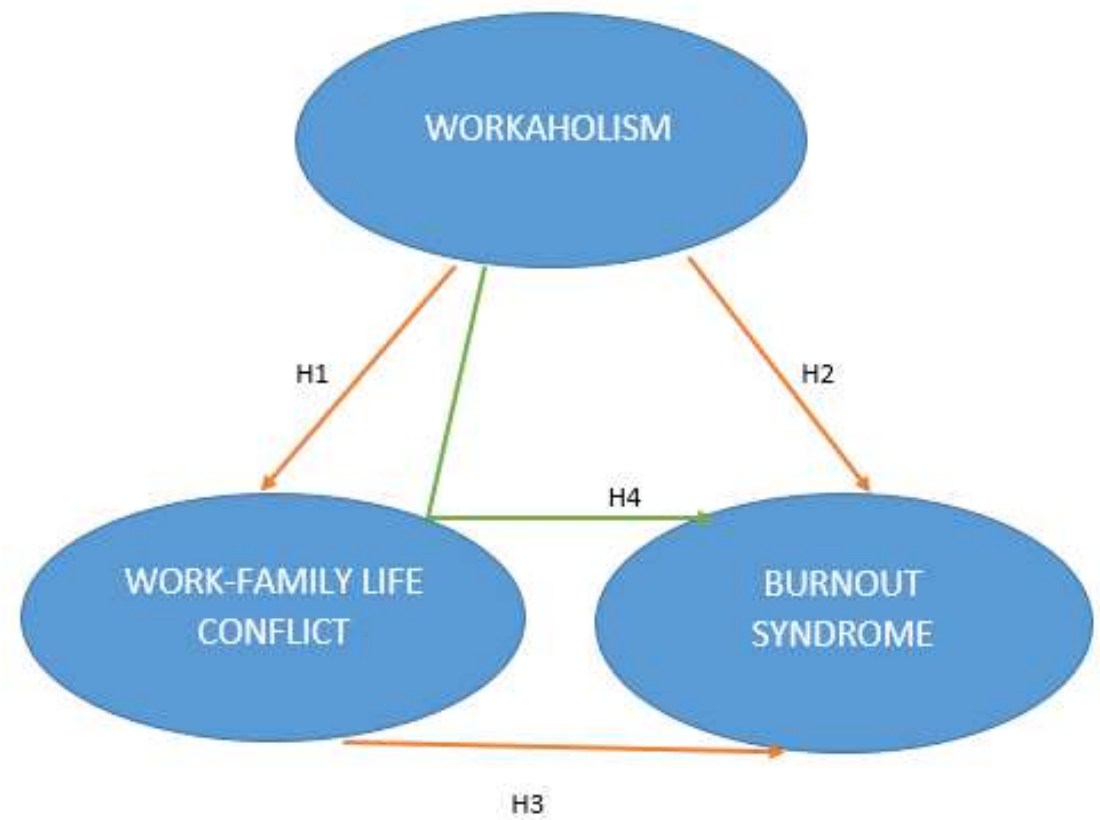

Figure 1. Research Model

\subsection{Sample}

The scope of the study is confined to female academicians of a state university in Konya. Recently, the increasing numbers and the significance of the females having careers have led to the choice of the University, which has a huge number of female academicians. The total number of the female academicians currently working at all the departments of the university is 651 , which is the scope of the present study. Some female academicians were not possible to be reached due to domestic assignments or assignments abroad, maternity leave, intensive physical examination duty, etc. A total number of 210 questionnaires were collected, 3 of which were incomplete and thus were left out. The final number of the sample was 207 female academicians. The representativeness of the sample size is $31.8 \%$.

\subsection{Limitations of the study}

Amongst all limitations, the leading ones are those related to time and economy. Data were collected in 2018, from May to November. In addition, the participants were assumed to have responded frankly and willingly on purposeful voluntary basis and in a way representing their own/genuine ideas, still it should be kept in mind that the participants might have had an inclination to respond in a non-objective manner not to have negative judgements against themselves/the institution.

\subsection{Instruments}

A questionnaire based on personal reflections was conducted as the data collection tool as part of the quantitative research design. The questionnaire consists of four parts. Part I is the demographic information part asking personal questions such as age, marital status, number of children, educational 
background, title, year of experience, department, administrative responsibilities and weekly teaching hours of the participant. Part II is the The Dutch Work Addiction Scale (DUWAS) which was developed by Schaufeli, Taris, and Bakker (2006) and adapted to Turkish by Doğan and Tel (2011). The scale aimed to measure workaholism levels of the participants- academicians in this case. The scale consists of 17 items, and 2 dimensions as "overworking/WE-working excessively" and "compulsive working/WC-working compulsively". In the third part, Netemeyer, Boles and McMurrian's (1996) WFC and FWC scales were used to measure female academicians' work-family life conflict levels. Originally developed by Netemeyer, Boles and McMurrian (1996), the scale was adapted to Turkish (Efeoğlu, 2006) with 10 items and 2 dimensions as work-family conflict (WF) and family- work conflict (FW). In the fourth part, as a measurement tool for burnout levels of the female academicians, MBI (Maslach Burnout Inventory) was used. Originally developed by Maslach and Jackson (1981), the scale was adapted by Ergin (1992) with 22 items, and 3 dimensions as "Emotional Exhaustion (EE)," "Depersonalisation (DP)" and "Personal Accomplishment (PA)." Reverse items within the Personal Accomplishment dimension are items (4-7-9-12-17-18-19-21) as they have negative statements. All measurement tools are 5-point Likert scales.

\subsection{Data collection \& Data analysis}

A total of number of 210 questionnaires were collected, 3 of which were incomplete and thus were left out. The final number of the questionnaires to be analysed was 207. The collected data were analysed through SPSS 25 and LISREL 9.1. Before analysing the data, to test the reliability of the scales used in the study, Cronbach Alpha- the value indicating internal consistency- was calculated. Frequency distribution, explanatory factor analysis, confirmatory factor analysis, correlation analysis, regression analysis and Structural Equation Model (SEM) were carried out.

\section{Results}

\subsection{Demographic Findings}

Demographic information related to the participants of the study- 207 female academicians- is presented in Table 1.

Table 1. Frequency distribution of female academicians' demographic information

\begin{tabular}{|c|c|c|c|c|c|c|}
\hline \multicolumn{2}{|c|}{ Parameters } & Frequency & $\%$ & Parameters & Frequency & $\%$ \\
\hline \multirow{4}{*}{ Age } & $21-30$ & 62 & 30.0 & Faculty of Education & 45 & 21.7 \\
\hline & $31-40$ & 91 & 44.0 & $\begin{array}{l}\text { Faculty of } \\
\text { Engineering/Architecture }\end{array}$ & 42 & 20.3 \\
\hline & $41-50$ & 41 & 19.7 & Faculty of Health Sciences & 33 & 15.9 \\
\hline & $51-+$ & 13 & 6.3 & Faculty of Dentistry & 16 & 7.8 \\
\hline \multirow[t]{3}{*}{ Marital Status } & Single & 66 & 31.9 & $\begin{array}{l}\text { Faculty of Social Sciences } \\
\text { and Humanities }\end{array}$ & 14 & 6.8 \\
\hline & Married & 141 & 68.1 & Faculty of Science & 10 & 4.8 \\
\hline & 0 & 80 & 38.6 & Faculty of Applied Sciences & 8 & 3.9 \\
\hline \multirow{4}{*}{$\begin{array}{l}\text { Number of } \\
\text { Children }\end{array}$} & 1 & 62 & 30.0 & Faculty of Political Sciences & 7 & 3.4 \\
\hline & 2 & 52 & 25.1 & Faculty of Tourism & 6 & 2.9 \\
\hline & 3 & 13 & 6.3 & Faculty of Fine Arts & 4 & 1.9 \\
\hline & Undergrad & 28 & 13.5 & 'Faculty of Law & 5 & 2.4 \\
\hline
\end{tabular}




\begin{tabular}{|c|c|c|c|c|c|c|}
\hline \multirow{4}{*}{$\begin{array}{l}\text { Educational } \\
\text { Background }\end{array}$} & Master & 47 & 22.7 & Ereğli Faculty of Education & 4 & 1.9 \\
\hline & Ph. D. & 132 & 63.8 & Vocational School of Justice & 4 & 1.9 \\
\hline & Prof. Dr. & 11 & 5.3 & $\begin{array}{l}\text { Faculty of Aviation and } \\
\text { Space Sciences }\end{array}$ & 3 & 1.4 \\
\hline & Assoc. Dr. & 23 & 11.1 & Ereğli Vocational School & 2 & 1.0 \\
\hline \multirow[t]{3}{*}{ Title } & $\begin{array}{l}\text { Assist. Prof. } \\
\text { Dr. }\end{array}$ & 78 & 37.7 & $\begin{array}{l}\text { Seydişehir Vocational } \\
\text { School }\end{array}$ & 2 & 1.0 \\
\hline & Lecturer & 34 & 16.4 & $\begin{array}{l}\text { Ereğli Faculty of } \\
\text { Engineering }\end{array}$ & 1 & 0.5 \\
\hline & Res. Assist. & 61 & 29.5 & Meram Vocational School & 1 & 0.5 \\
\hline \multirow{4}{*}{$\begin{array}{l}\text { Administrative } \\
\text { Responsibilities }\end{array}$} & Yes & 29 & 14.0 & No hrs. & 45 & 21.7 \\
\hline & No & 178 & 86.0 & $1-5 \mathrm{hrs}$. & 8 & 3.9 \\
\hline & $1-5 \mathrm{yrs}$. & 82 & 39.6 & छ 6-10 hrs. & 30 & 14.5 \\
\hline & $6-10 \mathrm{yrs}$ & 57 & 27.6 & $\underset{\text { D. }}{\text { I }} 11-15 \mathrm{hrs}$. & 65 & 31.4 \\
\hline \multirow{3}{*}{$\begin{array}{l}\text { Year of } \\
\text { Experience }\end{array}$} & $11-15$ yrs. & 35 & 16.9 & $\Xi 16-20 \mathrm{hrs}$. & 35 & 16.9 \\
\hline & $16-20 \mathrm{yrs}$ & 22 & 10.6 & 巴 $21-25 \mathrm{hrs}$. & 11 & 5.3 \\
\hline & $21-+$ & 11 & 5.3 & $226-30 \mathrm{hrs}$ & 6 & 2.9 \\
\hline \multirow{3}{*}{\multicolumn{2}{|c|}{ Total }} & 207 & 100.00 & d $31-35 \mathrm{hrs}$. & 5 & 2.4 \\
\hline & & & & 36-+ hrs. & 2 & 1.0 \\
\hline & & & & Total & 207 & 100.00 \\
\hline
\end{tabular}

As seen in Table 1, female academicians participating in the study were found to be between the ages of 31-40 (44\%), married (68.1\%), having no children (38,6\%), Ph. D. graduate (63.8\%), Assistant Prof. Dr. titled (37.7\%), having no administrative responsibilities $(86 \%)$, with 1-5 years of experience (39.6\%), working at Faculty of Education (21.7\%), with 11-15 weekly teaching hours (31.4\%) at most.

\subsection{Reliability and Validity of the Data Collection Tools}

Reliability co-efficient values of all the scales presented in Table 2 range between 0.754-0.916, which can be interpreted as the scales having high reliability.

Table 2. Reliability co-efficient of the Scales within the Study

\begin{tabular}{lcccccc}
\hline Scales & $\begin{array}{c}\text { 1st } \\
\text { number } \\
\text { of items }\end{array}$ & $\begin{array}{c}\mathbf{1}^{\text {st }} \\
\text { Cronbach's } \\
\text { alpha } \\
\text { coefficient }\end{array}$ & $\begin{array}{c}\text { Last } \\
\text { number } \\
\text { of items }\end{array}$ & $\begin{array}{c}\text { Last } \\
\text { Cronbach's } \\
\text { alpha } \\
\text { coefficient }\end{array}$ & $\begin{array}{c}\text { KMO } \\
\text { value }\end{array}$ & $\begin{array}{c}\text { Barlett's } \\
\text { value }\end{array}$ \\
\hline Workaholism & 17 & .889 & 13 & .892 & .849 & 1354.324 \\
Work-famiily life conflict & 10 & .916 & 10 & .916 & .883 & 1601.199 \\
Burnout & 22 & .756 & 16 & .754 & .828 & 1467.624 \\
\hline
\end{tabular}

Before the Explanatory Factor Analysis, Kaiser-Meyer-Olkin (KMO) was applied to check the appropriateness of the sample size for factor analysis. All the KMO values of the scales used within the scope of the research model were found to be over 0.60 and Bartlett values as 0.05 level of significance (see Table 2). According to the findings, it was concluded that sample size was sufficient for explanatory factor analysis. 


\subsection{Factor Analyses}

3.3.1. Explanatory factor analysis

Explanatory factor analysis results of the scales used in the study (Workaholism, Work-family life conflict, and Burnout syndrome) are presented and summarised in Table 3. (eigenfrequency: 1 and over; Factor load: 0.50 and over; variance ratio: $2 / 3$ of total variance)

Table 3. Explanatory factor analysis results of the scales used in the study

\begin{tabular}{|c|c|c|c|c|c|}
\hline \multicolumn{6}{|c|}{ Workaholism } \\
\hline Dimensions & Item & Factor load & Variance & $\begin{array}{c}\text { Cronbach's } \\
\text { Alpha }\end{array}$ & Eigenfrequency \\
\hline & W7 & .819 & & & \\
\hline Factor 1 & W16 & .811 & & & \\
\hline \multirow[t]{6}{*}{ Working excessively } & W11 & .771 & & & \\
\hline & W5 & 699 & 45.160 & .879 & 5.871 \\
\hline & W4 & .678 & & & \\
\hline & W13 & .635 & & & \\
\hline & W14 & .625 & & & \\
\hline & W9 & .527 & & & \\
\hline Factor 2 & W6 & .798 & & & \\
\hline Working & W17 & .793 & & & \\
\hline \multirow[t]{3}{*}{ compulsively } & W8 & .629 & 23.338 & 7.777 & 1.628 \\
\hline & W12 & .562 & & & \\
\hline & W2 & .544 & & & \\
\hline \multicolumn{6}{|c|}{ Work-Family Life Conflict Scale } \\
\hline Factor 1 & WFL2 & .896 & & & \\
\hline Work- Family & WFL3 & .886 & 38.800 & .929 & 5.711 \\
\hline \multirow[t]{3}{*}{ Conflict } & WFL4 & .882 & & & \\
\hline & WFL5 & .792 & & & \\
\hline & WFL1 & .773 & & & \\
\hline Factor 2 & WFL8 & .838 & & & \\
\hline Family-Work & WFL7 & .830 & & & \\
\hline \multirow{3}{*}{ Conflict } & WFL9 & .815 & 35.308 & .891 & 1.699 \\
\hline & WFL6 & .809 & & & \\
\hline & $\begin{array}{l}\text { WFL } \\
10\end{array}$ & .704 & & & \\
\hline \multicolumn{6}{|c|}{ Burnout Scale } \\
\hline & B2 & .823 & & & \\
\hline & B3 & .776 & & & \\
\hline & B8 & .769 & & & \\
\hline Factor 1: & B1 & .625 & 31.515 & .828 & 5.042 \\
\hline Emotional & B6 & 603 & & & \\
\hline \multirow[t]{3}{*}{ Exhaustion (EE) } & B20 & .586 & & & \\
\hline & B14 & .573 & & & \\
\hline & B5 & .807 & & & \\
\hline Factor 2: & B10 & .795 & & & \\
\hline Depersonalisation & B15 & 699 & 26.314 & .806 & 2.610 \\
\hline \multirow[t]{3}{*}{$(D P)$} & B11 & .677 & & & \\
\hline & B22 & .630 & & & \\
\hline & B19 & .822 & & & \\
\hline Factor 3: & B7 & .802 & & & \\
\hline Personal & B9 & .793 & 12.728 & .753 & 2.036 \\
\hline Accomplishment & B12 & .635 & & & \\
\hline$(P A)$ & B4 & .585 & & & \\
\hline
\end{tabular}


Considering the results of the factor analysis, it can be seen that two dimensions related to workaholism explain $68.498 \%$ of the total variance (Items of 1.-3.-10.-15. were deleted due to low and overlapping factor load); two dimensions related to work-family life scale explain $74.108 \%$ of the total variance; three dimensions related to burnout explain $70.557 \%$ of the total variance (Items of 13.-16.17.-18.-21. were deleted due to low and overlapping factor load).

\subsubsection{Confirmatory Factor Analysis}

Within the process of confirmatory factor analysis, a number of fit indices were adopted. Fit indices of the scales used in the research model are presented in Table 4.

Table 4. Fit indices of the scales used in the research model

\begin{tabular}{clccc}
\hline \multirow{2}{*}{ Fit indices } & & \multicolumn{3}{c}{ Fit indices of the scales } \\
\cline { 3 - 5 } & & Workaholism & $\begin{array}{c}\text { Work- Family } \\
\text { Life Conflict }\end{array}$ & Burnout Syndrome \\
\hline $\mathcal{H}^{2} / \mathrm{sd}$ & $\mathcal{\varkappa}^{2} / \mathrm{sd}<4$ (should be) & & 1,06 & 3,46 \\
RMSEA & $0,00<0,05=$ perfect fit & 0,05 & 0,03 & 0,07 \\
& $\leq 0,05-0,08=$ acceptable & perfect fit & perfect fit & acceptable \\
NFI & $\geq 0,95=$ perfect fit & 0,95 & 0,97 & 0,92 \\
& $\geq 0,90=$ acceptable & perfect fit & perfect fit & acceptable \\
NNFI & $\geq 0,95=$ perfect fit & 0,95 & 0,97 & 0,93 \\
& $\geq 0,90=$ acceptable & perfect fit & perfect fit & acceptable \\
CFI & $\geq 0,97=$ perfect fit & 0,95 & 0,98 & 0,95 \\
& $\geq 0,95=$ acceptable & perfect fit & perfect fit & acceptable \\
RFI & $\geq 0,95=$ perfect fit & 0,95 & 0,97 & 0,93 \\
& $\geq 0,90=$ acceptable & perfect fit & perfect fit & acceptable \\
GFI & $\geq 0,90=$ perfect fit & 0,90 & 0,92 & 0,88 \\
& $\geq 0,85=$ acceptable & perfect fit & perfect fit & acceptable \\
AGFI & $\geq 0,90=$ perfect fit & 0,89 & 0,91 & 0,87 \\
& $\geq 0,85=$ acceptable & acceptable & perfect fit & acceptable \\
IFI & $\geq 0,95=$ perfect fit & 0,95 & 0,98 & 0,90 \\
& $\geq 0,90=$ acceptable & perfect fit & perfect fit & acceptable
\end{tabular}

(Seçer, 2013, p.152)

As seen in Table 4, it can be inferred that the Burnout scale used within the research model was acceptable, and the other scales are perfect fit in terms of fit indices. The values indicate that all scales are statistically significant and valid.

\subsection{Correlation Analysis}

Pearson Correlation analysis (confidence interval of 95\% and with the level of $\mathrm{p}<0.01$ ) was calculated to see the relevance of the dimensions within the scales to each other, as seen in Table 5. 
Table 5. Correlation analysis between the dimensions of the scales used within the research model

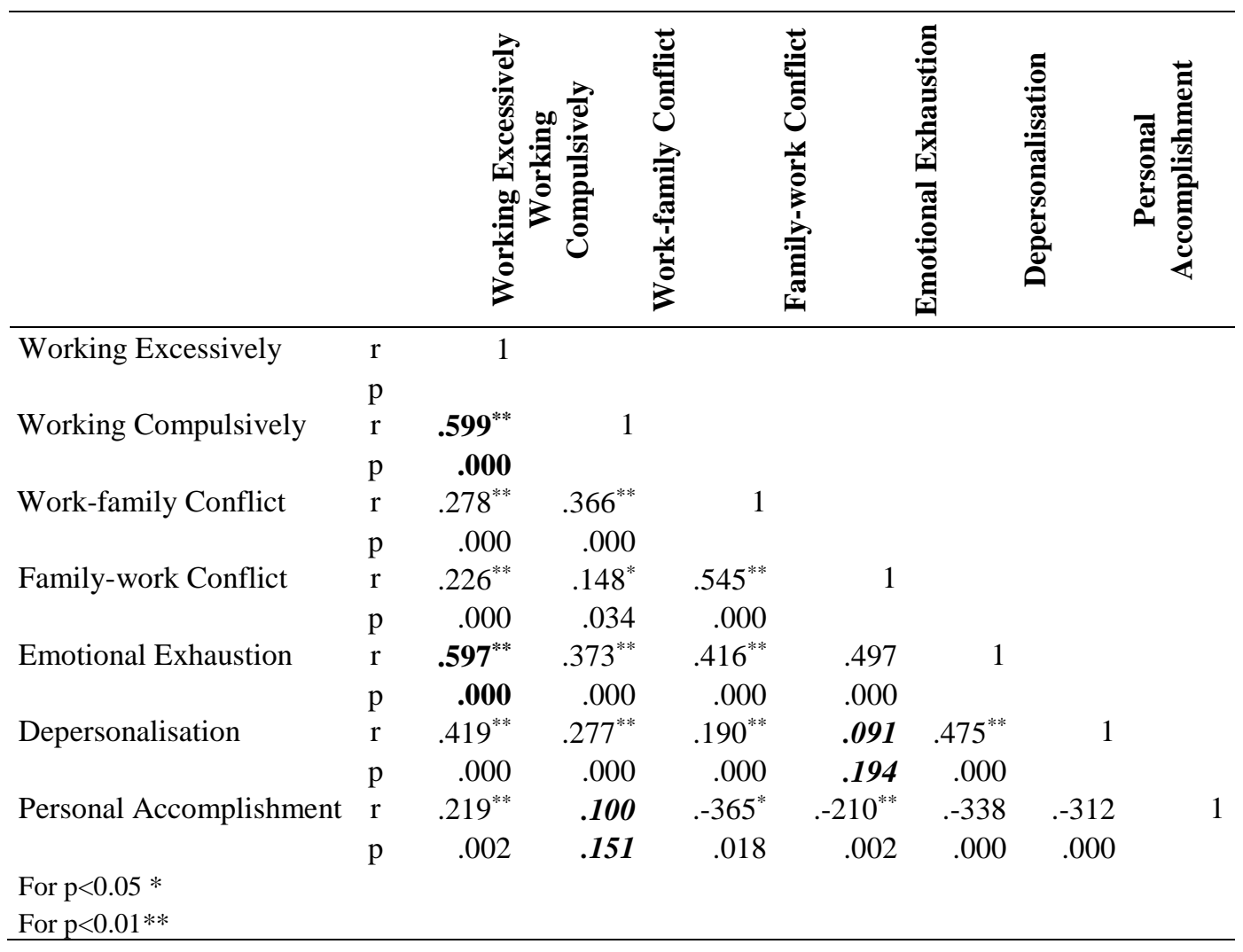

It can be easily inferred from Table 5 above that the highest positive correlation within the dimensions of the scales is between working compulsively and working excessively (.599). The highest correlation was found to be between that of emotional exhaustion and working excessively (.597) with regard to the correlation among all dimensions of all scales. However, no statistically valid and significant correlation was found between working compulsively dimension of workaholism scale and personal accomplishment dimension of burnout scale; and similarly, between family-work conflict dimension of work-family life conflict scale and depersonalisation dimension of burnout scale.

\subsection{Structural Equation Model}

Finalising the scales after the confirmatory factor analysis, the process started for the testification of the conceptual model set at the beginning of the research.

For the testification process through path analysis of the model set at the beginning of the research, $\mathrm{t}$-values were taken at the $5 \%$ level of significance, $\mathrm{t}$-value being $\mathrm{t}>1.96$., the research model aimed at looking into the correlation between latent variables. Hypothesis testing and evaluation of the research model is presented in Table 6 .

Table 6. Results of the hypothesis

\begin{tabular}{lllllll}
\hline Hypotheses & B & SH & $\boldsymbol{t}$ & $\boldsymbol{p}$ & Result \\
\hline $\begin{array}{l}\mathrm{H}_{1:} \quad \text { Workaholism levels of the female } \\
\text { academicians positively affect work-family life }\end{array}$ & 0.23 & .081 & 3.698 & 0.00 & Accepted \\
$\begin{array}{l}\text { conflict. } \\
\mathrm{H}_{2:} \quad \text { Workaholism levels of the female } \\
\text { academicians positively affect burnout levels. }\end{array}$ & 0.32 & .044 & 4.837 & 0.00 & Accepted \\
\hline
\end{tabular}




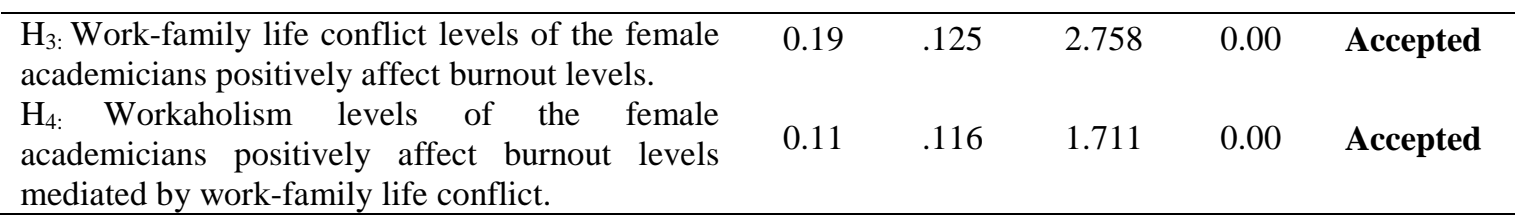

For testing the relations within the conceptual model set in line with the purpose of the study, as the first step of the hypothesis testing process, " $\mathrm{H}_{1}$ : Workaholism levels of the female academicians positively affect work-family life conflict." was tested and accepted according to the findings $(B=.23$ and $\mathrm{p}=.000$ ). Workaholism levels of female academicians were found to be significantly and positively affecting their work-family life conflict by $23 \%$.

Secondly, " $\mathrm{H}_{2}$ : Workaholism levels of the female academicians positively affect burnout levels." was tested and accepted $(\beta=.32$ and $p=0.00)$. It was found that workaholism levels of female academicians significantly and positively affected their burnout levels by $32 \%$.

Thirdly, " $\mathrm{H}_{3}$ : Work-family life conflict levels of the female academicians positively affect burnout levels." was tested and accepted. According to the findings, it was found out that $19 \%$ of the rise in the burnout levels of female academicians was related to work-family life conflict ( $\beta=.19$ and $p=0.00$ ).

Finally, " $\mathrm{H}_{4}$ : Workaholism levels of the female academicians positively affect burnout levels mediated by work-family life conflict." was tested and accepted $(\beta=.11$ and $p=0.00)$. Considering the data, it can be inferred that $11 \%$ of the female academicians' burnout levels resulted from the effect of workaholism levels mediated by work-family life conflict.

\section{Discussion}

The study aimed to investigate the case of female academicians in terms of burnout, workaholism, and work-family life conflict. The relationship of burnout with workaholism mediated by work-family life conflict was examined within the study. With this aim in mind, four hypotheses were formulated. The data collected was analysed through frequency distribution, explanatory factor analysis, confirmatory factor analysis, correlation analysis, and Structural Equation Model (SEM).

As with the first hypothesis, it can be concluded that the more workaholic an academician is, the more work-family life conflict she would have to face. Also suggested by other studies in the field (Bonebright, et. al., 2000; Brady et. al., 2008; Taris, et. al.,2010; Burke, 1999; Bakker et. al., 2009; Aziz \& Cunningham, 2008; Macit \& Ardıç, 2018), a significant amount of work-family life conflict resulted from workaholism. This can also be interpreted as preventing workaholism might lead to better standards for work-family life balance.

As with the second hypothesis, workaholism was also found to be a significant factor causing burnout of the female academicians. This can be interpreted as female academicians with higher levels of workaholism would be vulnerable to burnout, as well. Going in line with the other previous studies (Naktiyok \& Karabey, 2005; Andreassen, et al., 2007; Schaufeli, et al., 2008; Akın \& Oğuz, 2010; Metin, 2010; Macit \& Ardıç, 2018; Gülova, İspirli \& Eryılmaz, 2014; Taris, et al., 2010; Schaufeli, et al., 2009), the findings also suggested that workaholism levels of female academicians significantly and positively affected and increased their burnout levels.

As with the third hypothesis, another factor causing burnout was found to be the work-family life conflict levels of the female academicians. The more female academicians feel lack of control on the balance of work-family life, the more tendency they have towards burnout. Going in line with some other studies in the field (Rupert, et al., 2009; Bacharach, Bamberger \& Conley, 1991; Hill, et al., 2008; 
Gülova, et al., 2014), it was found out that burnout levels were positively affected by work-family life conflict.

Finally, as with the fourth hypothesis, the relations of the three elements were examined. Burnout was found to be affected by both workaholism and work-family life conflict. Considering the data, it can be concluded that female academicians suffered from burnout caused by workaholism mediated by work-family life conflict.

\section{Conclusion}

Female academicians comprise an increasing proportion of the academy. As with the results of the study, workaholism, work-family life conflict, and burnout are all related. As workaholism increases, so does the work-family life conflict. The more female academicians stand on the work part of the seesaw, the less they have balance. The more they become workaholics, the more they face work-family life conflicts. As they are stuck with what side to choose- either work or family- they start feeling helpless; as they become workaholics, it leads to burnout mediated by work-family life conflict.

Along with the results of the present study, the first thing to consider about female academicians might be that they were in a way experiencing at least one of the elements under study in some time during their careers. Having responsibilities at/outside work, female academicians need to have a balance between work \& family life. Once they choose either work or family, they neglect the other only if they have a perfect balance. Even when they have balance, they neglect themselves finally- which is not the happy ending as expected.

There arises a need for better working environments where female academicians have awareness towards workaholism, effective working is widespread, cooperation but not competition is enhanced, female academicians are not prevented by the work-family life conflict in terms of creativity, productivity, and commitment. Then it would be possible to consider "commitment" rather than "work addiction." A term used for the feelings of loyalty, involvement, and commitment to the workplace, organisational commitment in academic context might be regarded as a factor related to quality of teaching, student- satisfaction, higher levels of job satisfaction, lower levels of burnout, better perceptions towards responsibilities. In this respect, it is crucial to fight against and remove the obstacles related to work-overload, family-bound responsibilities, societal pressure \& prejudice, sexist points of view, and thus develop and improve organisational commitment and self-confidence.

Female academicians with higher self-confidence would be hopeful for the future, work effectively and efficiently, positively affect other academicians' points of views. Through seminars, trainings, and guidance, female academicians might be supported in terms of self-confidence, time and stress management, and get rid of the feeling of "learned helplessness," better succeed in academic life. These seminars would also be effective in raising awareness towards workaholism, having strategies to cope with burnout, finally having a healthy work-family life balance.

Female academicians are becoming more significant and indispensable in academic life. Therefore, supporting female academicians and clearing the way for them would flourish in creativity, productivity, and better-qualified studies. There would also be a need for the support of the male colleagues in terms of better working environments with conditions based on sense of equity. Workshops on collaborative team work, awareness on equal standards might be effective for fighting against burnout, workaholism, and work-family life conflict. 


\section{References}

Akın, U., \& Oğuz, E. (2010). Öğretmenlerin işkoliklik ve tükenmişlik düzeylerinin ilişkisi ve çeşitli değişkenler açısından incelenmesi. Kuram ve Uygulamada Eğitim Yönetimi, 16(3), 309-327.

Arslan, R., \& Acar, B.N. (2013). A research on academics on life satisfaction, job satisfaction, and professional burnout. Suleyman Demirel University The Journal of Faculty of Economics and Administrative Sciences, 18(3), 281-298.

Andreassen, C., Ursin, H., \& Eriksen, H. (2007). The relationship between strong motivation to work, "workaholism", and health. Psychology \& Health, 22, 615-629.

Aziz, S., \& Cunningham, J. (2008). Workaholism, work stress, work-life imbalance: exploring gender's role. Gender in Management: An International Journal, 23(8), 553-566, https://doi.org/10.1108/17542410810912681

Bacharach, S.B., Bamberger, P., \& Conley, S. (1991). Work-home conflict among nurses and engineers: Mediating the impact of role stress on burnout and satisfaction at work. Journal of Organisational Behaviour, 12(1), 39-53, https://doi.org/10.1002/job.4030120104

Bakker, A. B., Demerouti, E., \& Burke, R. (2009). Workaholism and relationship quality: A spillovercrossover perspective. Journal of Occupational Health Psychology, 14, 23-33.

Bonebright, C. A., Clay, D. L., \& Ankenmann, R. D. (2000). The relationship of workaholism with work-life conflict, life satisfaction, and purpose in life. Journal of Counseling Psychology, 47(4), 469-477, http://doi.org/10.1037/0022-0167.47.4.469

Brady, B. R., Vodanovich, S. J., \& Rotunda, R. (2008). The impact of workaholism on work-family conflict, job satisfaction, and perception of leisure activities. The Psychologist-Manager Journal, $11,241-263$.

Budak, G., \& Sürgevil, O. (2005). Tükenmişlik ve tükenmişliği etkileyen örgütsel faktörlerin analizine ilişkin akademik personel üzerinde bir uygulama. DEÜ İIBF Dergisi, 20(2), 95-108.

Burke, R. J. (1999). Work and extra work satisfactions. International Journal of Organizational Analysis, 7(4), 352- 365.

Burke, R. J., \& Greenglass, E.R. (2001). Hospital restructuring and psychological burnout in nursing staff. Equal Opportunities International, 20(1/2), 61-71, https://doi.org/10.1108/02610150110786714

Chan, D. W. (2007). Burnout, self-efficacy, and successful intelligence among Chinese prospective and in-service school teachers in Hong-Kong. Educational Psychology: An International Journal of Experimental Educational Psychology, 27(1), 33-49.

Çapri, B. (2006). Tükenmişlik ölçeğinin Türkçe uyarlaması: geçerlik ve güvenirlik çalışması. Mersin Üniversitesi Eğitim Fakültesi Dergisi, 2(1), 62-77.

Doğan, T., \& Tel, F. D. (2011). Duwas işkoliklik ölçeği Türkçe formunun (Duwas Tr) geçerlik ve güvenirliğinin incelenmesi. AİBÜ Eğitim Fakültesi Dergisi, 11(1), 61-69.

Doyle, C., \& Hind, P. (1998). Occupational stress, burnout and job status in female academics. Gender, Work \& Organisation. 5(2), 67-82.

Efeoğlu, İ. E. (2006). Işs-aile yaşam çatışmasının iş stresi, iş doyumu ve örgütsel bağlllık üzerindeki etkileri: ilaç sektöründe bir araştırma, Unpublished MA thesis, Çukurova University, Adana, Turkey. 
Engelbrecht, M., Berg, H., \& Bester, C. (2009). Burnout and compassion fatique: the case of professional nurses in primary health care facilities in the free state province, South Africa. In R. Schwartzhoffer (Ed.), Psychology of Burnout: Predictors and Coping Mechanisms (pp.1-38). New York: Nova Science Publishers.

Ercan Demirel, E. E. (2014). A research study of teacher beliefs and teacher burnout, Ph.D dissertation, Gazi University, Ankara, Turkey.

Ercan Demirel, E., \& Cephe, P.T. (2015). Looking into burnout levels among English language instructors. Journal of Language and Linguistic Studies, 11(1), 1-14.

Ergin, C. (1992). Doktor ve hemşirelerde tükenmişlik ve Maslach Tükenmişlik Ölçeğinin uyarlanması. VII. Ulusal Psikoloji Kongresi, Hacettepe Üniversitesi, Ankara.

Freudenberger, H. J. (1974). Staff burnout. Journal of Social Issues, 30, 159-165.

Greenglass, E.R., Burke, R.J., \& Konarski, R. (1998). Components of burnout, resources, and genderrelated differences. Journal of Applied Social Psychology, 28(12), 1088-1106.

Greenhaus, J., \& Beutell, N. J. (1985). Sources of conflict between work and family roles. The Academy of Management Review, 10(1), 76-88.

Gülova, A.A., İspirli, D., \& Eryılmaz, İ. (2014). İşkoliklik ve tükenmişlik arasındaki ilişkinin incelenmesine yönelik beyaz yakalılar üzerine bir çalışma. Pamukkale Üniversitesi Sosyal Bilimler Enstitüsü Dergisi, 19, 25-39.

Hooigard, R., Giske, R., \& Sundsli, K. (2011). Newly qualified teachers' work engagement and teacher efficacy influences on job satisfaction, burnout, and the intention to quit. European Journal of Teacher Education, 1-11, https://doi.org/10.1080/02619768.2011.633993

Hill, E.J., Jacob, J.I., Shannon, L.L., Brennan, R.T., Blanchard, V.L., \& Martinengo, G.M. (2008). Exploring the relationship of workplace flexibility, gender, and life stage to family-to-work conflict, and stress and burnout. Community, Work and Family, 11(2), 165-181, https://doi.org/10.1080/13668800802027564

Khan, F., Khan, Q., \& Naz, A. (2016). Female academicians are burnout in Pakistan Universities. Gomal University Journal of Research, Special Issue, 157-167.

Kossek, E. E., \& Ozeki, C. (1998). Work-Family Conflict, Policies, and The Job-Life Satisfaction Relationship: A Review and Directions for Organizational Behavior-Human Resources Research. Journal of Applied Psychology, 83(2), 139-149.

Macit, M. (2015). İşkoliklik, iş-aile çatişmasi ve tükenmişlik ilişkileri üzerine bir araştırma, Ph. D. Dissertation, Gaziosmanpaşa University, Tokat, Turkey.

Macit, M., \& Ardıç, K. (2018), İşkoliklik, iş-aile çatışası ve tükenmişlik arasındaki ilişkinin incelenmesi üzerine bir araştırma, Atatürk Üniversitesi İktisadi ve İdari Bilimler Dergisi, 32(3), 825-844.

Maslach, C. (1976). Burned-Out. Human Behavior, 9, 16-22.

Maslach, C. (1999). Progress in understanding teacher burnout. In R. Vandenberghe \& A.M. Huberman (Eds.), Understanding and preventing teacher burnout: A sourcebook of international research and practice (pp.211-222). Cambridge, UK: Cambridge University Press.

Maslach, C. (2003). Burnout: The cost of caring. California: ISHK.

Maslach, C. \& Jackson, S.E. (1981). The measurement of experienced burnout. Journal of Occupational Behaviour, 2, 99-113. 
Maslach, C., Schaufeli, W. B., \& Leiter, M. P. (2001). Job burnout. Annu. Rev. Psychol, 52, 397-422.

Melendez, W.A., \& Guzman, R. M. (1983). Burnout: The New Academic Disease. ASHE-ERIC Higher Education Research Report, 9.

Metin, Ü. B. (2010). The Antecedents and Consequences of Burnout, Work Engagement and Workaholism. METU Graduate School of Social Sciences, Unpublished MA thesis, Ankara, Turkey.

Naktiyok, A., \& Karabey, C. N. (2005). İşkoliklik ve tükenmişlik sendromu, İktisadi ve İdari Bilimler Dergisi, 19(2), 179-198.

Netemeyer, R. G., Boles, J.S., \& McMurrian, R. M. (1996). Development and validation of work-family conflict and family-work conflict scales. Journal of Applied Psychology. 81(4), 400-410.

Oates, W. (1971). Confessions of a workaholic: The facts about work addiction. NewYork, NY: World Publishing.

Özkin, F. (2015). İş-aile yaşam dengesi ve yıldırmanın işten ayrllma niyetine etkisi: tükenmişliğin aracıllk rolü, Mustafa Kemal University, MA Thesis, Hatay, Turkey.

Porter, G. (1996). Organisational impact of workaholism: suggestions for researching the negative outcomes of excessive work. Journal of Occupational Health Psychology, 1(1), 70-84.

Rampal, L., \& Shahar, H.K. (2014). Prevalence of burnout and its associated factors among faculty academicians. Malaysian Journal of Medicine and Health Sciences, 10(1), 51-59.

Rupert, P. A., Stevanovic, P., \& Hunley, H. A. (2009), Work-family conflict and burnout among practicing psychologists, Professional Psychology: Research and Practice, 40(1), 54-61, http://dx.doi.org/10.1037/a0012538

Schaufeli, W., \& Enzmann, D. (1998). The burnout companion to study and practice. A critical analysis. London: Taylor\&Francis.

Schaufeli, W., Salanova, M., Gonzalez-Roma, V., \& Bakker, A. B. (2002). The measurement of engagement and burnout: a two-sample confirmatory factor analytic approach. Journal of Happiness Studies, 3, 71-92. Netherlands: Kluwer Academic Publishers.

Schaufeli, W. B., Taris, T.W., \& Bakker, A. (2006). Dr. Jekyll and Mr. Hide: On the differences between work engagement and workaholism. In R. Burke (Ed.), Research companion to working time and work addiction (pp. 193-217). Edward Elgar: Northampton, MA.

Schaufeli, W. B., Taris, T. W. \& Rhenen, W. (2008). Workaholism, burnout, and work engagement:three of a kind or three different kinds of employee well-being?. Applied Psychology: An International Review. 57(2), 173-203, doi: 10.1111/j.1464-0597.2007.00285.x

Schaufeli, W. B., Taris, T. W., \& Bakker, A. B. (2008). It takes two to tango: Workaholism is working excessively and working compulsively. In R. J. Burke \& C. L. Cooper (Eds.), The long work hours culture: Causes, consequences and choices (pp. 203-226). Bingley, UK: Emerald.

Schaufeli, W. B., Bakker, A.B. \& M.M.A Van Der Heijden, F., Prins, J.T. (2009). Workaholism, burnout and well-being among junior doctors: the mediating role of role conflict, Work\&Stress, 23(2), 155172.

Shimazu, A., \& Schaufeli, W. B. (2009). Is workaholism good or bad for employee well-being? The distinctiveness of workaholism and work engagement among Japanese employees. Industrial Health, 47, 495-502. 
Seçer, İ. (2013). SPSS ve LISREL ile pratik veri analizi, analiz ve raporlaştırma, Anı Publishing, Ankara.

Skaalvik, E.M., \& Skaalvik,S. (2010). Teacher self-efficacy and teacher burnout: a study of relations. Teaching and Teacher Education, 26, 1059-1069.

Stoeber J., Damian L. (2016) Perfectionism in employees: work engagement, workaholism, and burnout. In Sirois F., Molnar D. (Eds.) Perfectionism, Health, and Well-Being (pp.265-283). New York: Springer.

Taris, T.W., Beek, I., \& Schaufeli, W.B. (2010). Why do perfectionists have a higher burnout risk than others? the mediational effect of workaholism. Romanian Journal of Applied Psychology, 12(1), 17.

Taris, T. W., Van Beek, I., \& Schaufeli, W. B. (2012). Demographic and occupational correlates of workaholism, Psychological Reports, 110(2), 547-554.

Tuğsal, T., \& Ülgen, B. (2017). Work-life balance and social support as predictors of burnout: an exploratory analysis. International Journal of Academic Research in Business and Social Sciences, 7, 117-138, http://doi.10.6007/IJARBSS/v7-i3/2699

Toker, B. (2011). Burnout among university academicians: an empirical study on the universities of Turkey. Doğuş Üniversitesi Dergisi. 12(1), 114-127.

Troppmann, K.M., \& Troppmann, C. (2012). Work-Life Balance and Burnout. In Chen H., Kao L. (Eds.) Success in Academic Surgery: Part 1(219-234). New York: Springer https://doi.org/10.1007/978-085729-313-8_14

Vandenberghe, R., \& Huberman, A.M. (1999). Understanding and preventing teacher burnout. UK: Cambridge University Press.

Watts, J., \& Robertson, N. (2011). Burnout in university teaching staff: a systematic literature review. Educational Research, 53(1), 33-50.

\section{Tükenmişliğin iş-aile yaşam çatışması aracılığıyla işkoliklikle ilişkisi: Kadın akademisyenler üzerine bir araştırma}

$\ddot{O} \mathbf{z}$

Rekabetçi akademik hayatın bir parçası olan öğretim elemanlarının; eğitimin devamlılığı, yayın yapma, memnuniyetsizliklerle baş etme gibi pek çok sorumluluk ve baskının altında ezilmekte olduğu ve böylece de artan stresle birlikte tükenmişlikle yüzleşmek zorunda kaldığı söylenebilir (Melendez\&Guzman,1983).

Kurumsal, idari ve öğretimle ilgili pek çok sorumlulukla birlikte, kadın akademisyenler; annelik, eş durumu, evle ilgili sorumluluklar gibi diğer rolleri de yürütmekle yükümlü görülürler. Akademik hayatın tam da içinde yer alan ve bir kadın akademisyen olarak hem akademik hayatla hem de aile hayatıyla ilgili pek çok farklı rolü aynı anda yürütmeye çalışan araştırmacılar, kadın akademisyenlerin bu durumlarıyla ilgili bir çalışma yapma arzusu ve baskısını derinden hissetmişlerdir. 
Bu makale kadın akademisyenlerin tükenmişlik, işkoliklik ve iş-aile-yaşam çatışması bakımlarından durumlarını ortaya koymayı amaçlamaktadır. Çalışmada, tükenmişliğin, iş-aile-yaşam çatışması aracılığıyla, işkoliklikle ilişkisi araştırılmıştır.

Veri toplama aracı olarak, nicel araştırma yöntemlerinden kişisel görüşlere dayalı anket tekniği kullanılmıştır. Çalışmada kullanılan anket 4 bölümden oluşmaktadır. Araştırma evreni Konya'da bir devlet üniversitesinin kadın akademisyenleriyle sınırlıdır. Söz konusu üniversitenin tüm bölümlerinde halen çalışmakta olan kadın akademisyenlerin toplam sayısı, araştırmanın evrenini de oluşturan 651 kadın akademisyendir. Toplamda 210 adet anket doldurulmuş, ancak 3 anket eksik doldurulduğundan analize alınmamıştır. Bu nedenle örneklemi 207 kadın akademisyen oluşturmuştur. Örneklemin evreni temsil oranı \%31,8'dir. Araştırmada toplanan verilerin analizinde frekans dağılımı, açıklayıcı faktör analizi, doğrulayıcı faktör analizi, korelasyon analizi ve Yapısal Eşitlik Modeli (YEM) yapılmıştır.

İş-aile-yaşam çatışmasının \%23'ünün işkoliklik ile ilişkili olduğu ortaya çıkmıştır. Kadın akademisyenlerin tükenmişlik seviyelerinin \%32'sinin işkoliklik seviyeleriyle ilişkili olduğu bulunmuştur. Kadın akademisyenlerin tükenmişlik düzeylerindeki artışının \%19'unun iş-aile-yaşam çatışması ile ilişkili olduğu sonucu bulunmuştur. Kısacası kadın akademisyenlerin iş-aile-yaşam çatışması düzeyleri, tükenmişlik seviyelerini anlamlı ve pozitif yönde etkilemektedir. Son olarak, kadın akademisyenlerin tükenmişlik seviyelerinin \%11'inin iş-aile-yaşam çatışması aracılığıyla işkoliklik düzeylerinden kaynaklandığı ortaya çıkmıştır.

Anahtar sözcükler: kadın akademisyenler; tükenmişlik; işkoliklik; iş-aile yaşam çatışması; yapısal eşitlik modeli (YEM).

\section{AUTHOR BIODATA}

Dr. Eda ERCAN DEMIREL received her Ph.D. degree at Gazi University ELT department in 2014. She is currently teaching at NEU ELT Department as an assistant professor. Her special interests are teacher burnout, foreign language teacher education \& teacher development, teaching methods, materials design, and technology in language teaching.

Dr. Meral ERDİRENÇELEBİ received her Ph.D. in 2012 in the Department of Business Administration. Currently, she is an academician at Necmettin Erbakan University Applied Sciences Faculty Banking Department. She is specialized on organizational behavior. Her studies are on entrepreneurship, woman entrepreneurship, family business, and current issues at organizational behavior (presenteeism, burnout, intention to leave, nepotism, organizational loneliness, workaholism, work-life balance, emotional labor, etc). 